\title{
A Rare Cause of Urinary Retention in Women: Urethral Caruncle
}

\author{
Kadınlarda Üriner Retansiyonun Nadir Bir Nedeni: Üretral Karunkül
}

\author{
Engin Kolukcu', Tufan Alatli², Faik Alev Deresoy³', Latif Mustafa Ozbek', Dogan Atilgan'1 \\ ${ }^{1}$ Department of Urology, Tokat Gaziosmanpasa University Faculty of Medicine, Tokat; ${ }^{2}$ Department of Emergency, Balikesir University \\ Faculty of Medicine, Balikesir; ${ }^{3}$ Department of Pathology, Tokat Gaziosmanpasa University Faculty of Medicine, Tokat; ${ }^{4}$ Department of \\ Urology, Private Atasam Hospital, Samsun, Turkey
}

\begin{abstract}
Urethral caruncle is a benign lesion commonly encountered in women. Most of these lesions are smaller than $1 \mathrm{~cm}$ and are asymptomatic. In the present case report, the case of a 39 years old woman who applied to emergency department with acute urinary retention due to urethral caruncle was discussed with a literature review.
\end{abstract}

Key words: female; urinary retention; caruncle

\section{ÖZET}

Kadınlarda üretral karunkül sık gözlenen benign bir lezyondur. Bu lezyonların büyük bir bölümü $1 \mathrm{~cm}$ altında olup asemptomatik seyretmektedir. Bu olgu sunumunda akut üriner retansiyon ile acil departmanına bașvuran ve üretral karunkül tanısı konulan 39 yașındaki kadın hastanın literatür bilgileri altında tartıșılması amaçlanmıștır.

Anahtar kelimeler: kadın; üriner retansiyon; karunkül

\section{Introduction}

Urethral caruncle is one of the most commonly encountered benign lesions of female urethra. These benign formations can be seen in all age groups, but are often observed in the postmenopausal period. Urethral caruncles originate from the urethra posterior wall and mostly come out of the urethral mea, so that lesions can only be diagnosed based on palpation. Urethral caruncles are observed in urogynecological examination as soft pink or red polypoid nodules, which usually protrude from urethral meatus. These lesions are mostly less than $1 \mathrm{~cm}$ and are asymptomatic ${ }^{1,2}$. However, patients can apply with very different symptoms such as hematuria, urethrorrhagia, dystonia, weak urine stream and urinary retention ${ }^{2-4}$. Almost all of the symptoms are directly related to the size of lesions. The aim of this study was to present a urethral caruncle case in which the caruncle did not reach a large size but caused acute urinary retention.

\section{Case}

A 39-year-old female patient was admitted to our emergency department with urinary retention and abdominal pain for the last 12 hours. The patient had no features on her anamnesis except for an endoscopic stone surgery she underwent 19 years ago due to left ureteral stone. Globe vesicle was found in the physical examination. Her body temperature was $37.2^{\circ} \mathrm{C}$, pulse was 97 rhythmic, and blood pressure was $130 / 90 \mathrm{mmHg}$.

IIetișim/Contact: Engin Kolukcu, Tokat Gaziosmanpasa University Faculty of Medicine, Department of Urology, Tokat, Turkey • Tel: 05354002385 • E-mail:drenginkolukcu@gmail.com • Geliș/Received:27.03.2020 • Kabul/Accepted:09.07.2020

ORCID: Engin Kölükçü, 0000-0003-3387-4428 • Tufan Alatli, 0000-0002-7858-8081 • Faik Alev Deresoy, 0000-0003-3387-4428 • Latif Mustafa Özbek, 0000-0002-0459-7305 • Doğan Atrlgan, 0000-0001-8584-2124 


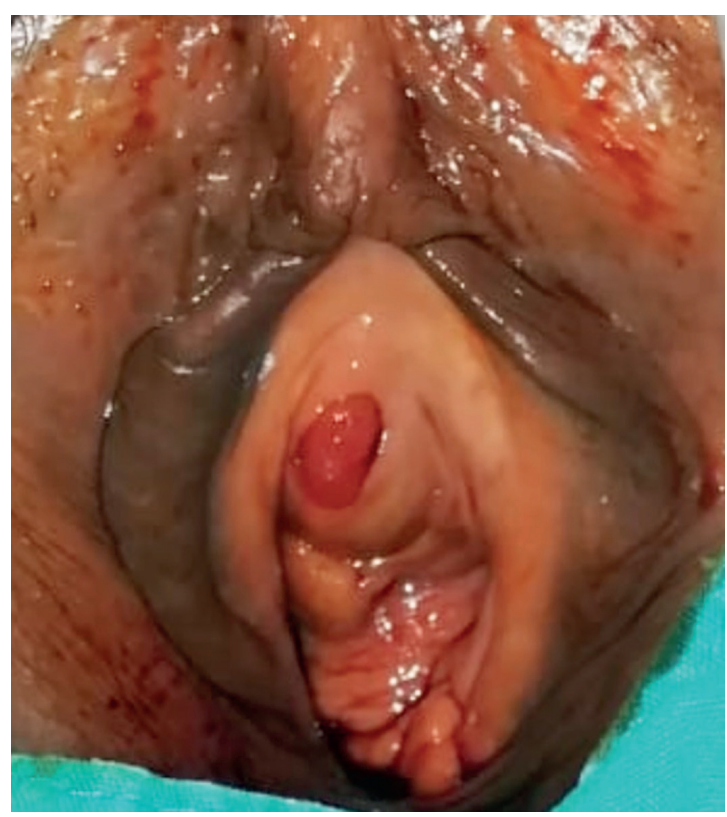

Figure 1. Red polypoid lesion extending out of the urethral meatus.

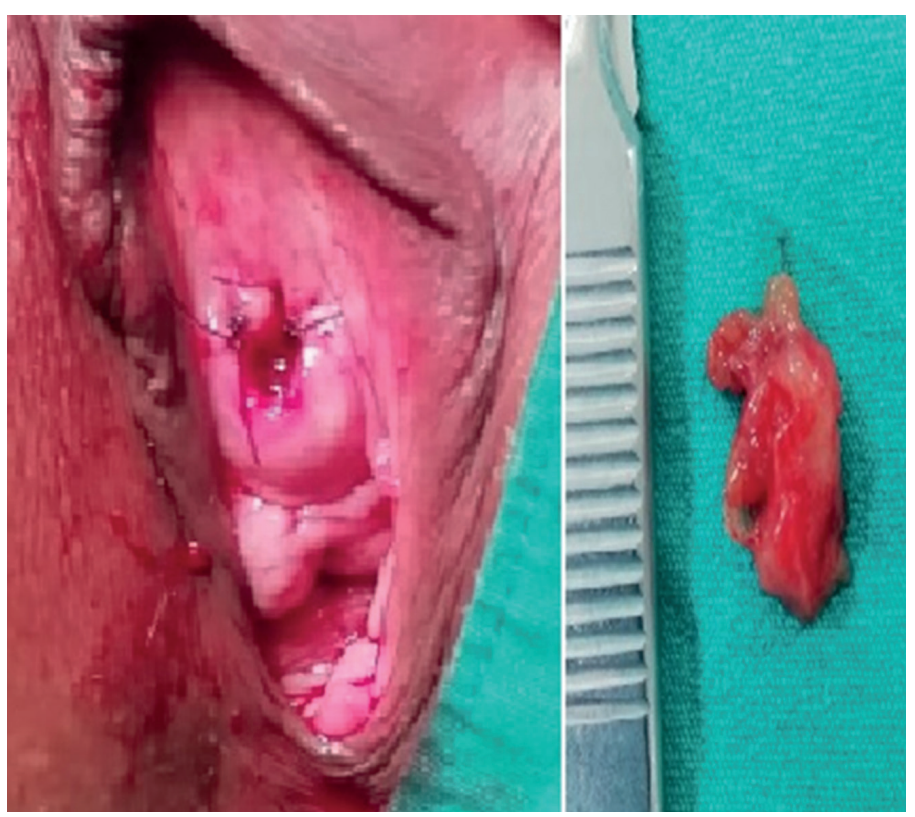

Figure 2. Postoperative genitourinary system examination and macroscopic view of the lesion.
Laboratory test results were as follows: serum creatinine $1.14 \mathrm{mg} / \mathrm{dl}$, urea $21.31 \mathrm{mg} / \mathrm{dl}$, hemoglobin 14.12 $\mathrm{g} / \mathrm{dl}$ and white blood cell count $8100 / \mathrm{mm} 3$. Urine analysis confirmed albumin +1 , white blood cells $7-9 /$ high power field (HPF), negative nitrite and absent casts. Bilateral grade 1 ectasia was observed in urinary ultrasonography. No growth was detected in the urinary culture. Prompt urethral excision was planned for the patient. During the procedure, $1.5 \times 2 \mathrm{~cm}$ polypoid lesion in light red, protruding from the urethral meatus and originating from the posterior wall, was observed (Figure 1). A small urethral catheter (12 French) was inserted and the bladder emptied. Approximately 900 cc of urine output was observed. Cystourethroscopy was performed with spinal anesthesia under sterile conditions in operating room. The lesion was found to be limited to the urethral. Urethral caruncle was excised and no complication occurred during the operation (Figure 2). The patient was followed with 18 french catheters for 5 days. Postoperative course was uneventful. Histopathological examination of the surgery specimen showed polypoid structure of an inflammatory granulation tissue appearance with severe mixed-type inflammatory cell infiltrations where the surface was lined with slight hyperplastic urothelium with edema, congestion and hemorrhage areas under the epithelium. No pathological findings were found in favor of neoplastic development in surface epithelium or stromal areas (Figure 3, 4). Tissue analysis evaluated by two pathologists was reported as urethral caruncle. After a three-week postoperative follow-up, she was asymptomatic without any findings in the physical examination and urinary ultrasonography. In uroflowmetry analysis, the maximum and average flow rates were 16.5 and $9.7 \mathrm{ml} / \mathrm{s}$, respectively. Written consent was obtained from the patient.

\section{Discussion}

Acute urinary retention is among the most common urological complaints encountered in emergency clinics. This condition is characterized by the inability to make a sudden urination, and often occurs as secondary to prostate hyperplasia in older male patients. This disorder is extremely rare in women, and an incidence rate of 3 to 7 per 100,000 people in a year was reported in epidemiological studies with large series ${ }^{5,6}$. Pathophysiology of the acute urinary retention includes many diverse factors such as decrease in bladder contractility, poor sustaining of detrusor contraction, impaired outlet relaxation, insufficient anatomical outlet and neurological disorders ${ }^{7}$. As the anatomical causes that prevent urine flow from the bladder, many factors are listed such as obstruction in primary bladder neck, cystocele, rectocele, foreign bodies, uterine prolapse, urethral diverticulum, history of stress 


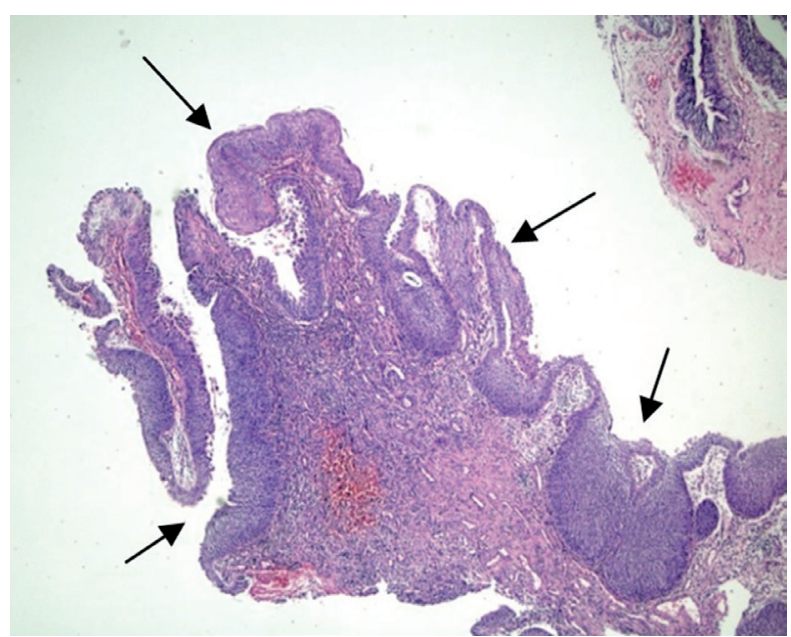

Figure 3. Morphology of polypoid lesion whose surface is covered with hyperplastic urothelium.

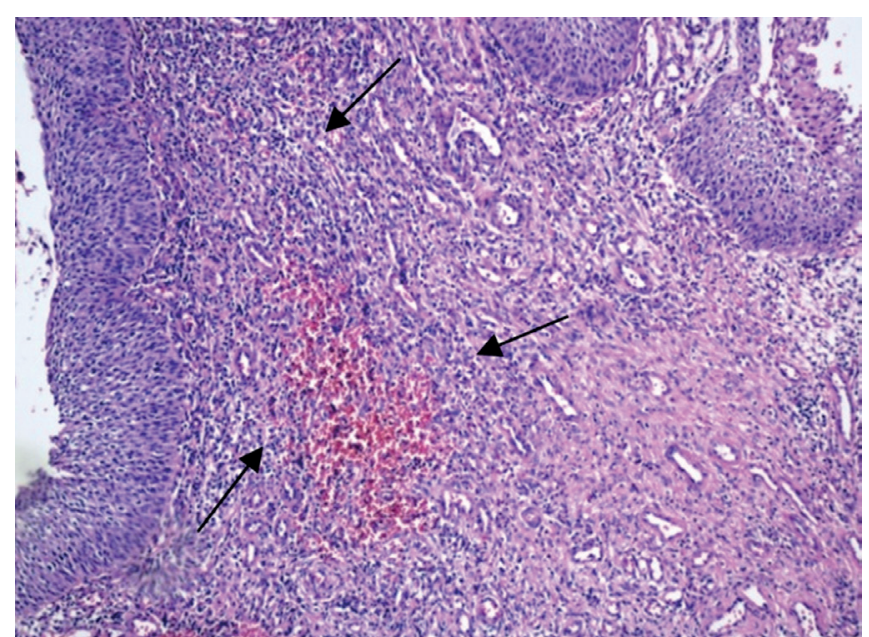

Figure 4. Caruncle stroma, edema, congestion, densely vascularized and inflammatory granulation tissue with hemorrhage areas. incontinence surgery or endourological intervention ${ }^{7,8}$. When urethral caruncles reach large dimensions, they could result in bladder outlet obstructions, albeit extremely rarely, and play roles in etiology of acute urinary retention. In the present study, a urethral caruncle case which caused urinary obstruction, although it did not reach a large dimension, was presented. Changes in the natural structure of urethra secondary to endoscopic ureteral stone surgery the patient underwent 19 years ago was suggested to play a role in this patient.

Urethral caruncle was first identified by Samuel Sharp in 1750. After almost three centuries of identification, its etiopathogenesis is still not fully illuminated. Many factors such as recurrent infections, chronic irritation, estrogen insufficiency and chronic inflammatory diseases with chronic granulation tissue formation are blamed for its etiology $y^{4,9}$. Histologically, urethral caruncles could have papillomatous, angiomatous or granulomatous morphology. Microscopic examination of lesions showed inflammatory granulation tissue characterized by common congested vascular structures and infiltration of mixed type inflammatory cells whose surface is lined with urothelium in loose fibroblastic stroma under the epithelium. On the other hand, hyperplastic areas could be observed on the surface epithelium. However, it could also be observed that the surface epithelium forms cystic or glandular structures as a result of its invagination into sub-epithelium stromal areas ${ }^{9,10}$. Previous studies mentioned that malignancy could be encountered postoperatively, albeit rarely. Marshall et al. ${ }^{11}$ reported that in a case series of 376 patients who were operated with urethral caruncle pre-diagnosis, pathological evaluation of postoperative tissue samples indicated malignancies in $2.4 \%$ of cases. Many pathologies that clinically mimic urethral caruncles and need to be considered during the differential diagnosis were reported such as infected urethral diverticulum, ectopic ureterocele, vaginal wall cyst, Gartner canal cyst, Skene's gland abscess, Mullerian duct cyst, tuberculosis, urethra carcinoma, urethra malignant melanoma, urethral leiomyoma, intraepithelial squamous cell carcinoma, intestinal metaplasia, lymphoma, clitoral vein thrombosis, ureteral polyps and angiomatous lesions ${ }^{1,12}$.

In the treatment of urethral caruncles, topical estrogen creams, steroid pomades, anti-inflammatory agents and cryoablation could be used for small-size lesions. The effectiveness of these treatment approaches is limited and does not allow histopathological evaluation of lesions. Surgical excision of lesions that become symptomatic or reach to large dimensions is a treatment strategy accepted by many authors ${ }^{2,3,9}$. Similarly, urethral caruncle was surgically excised in our case and the urethral obstruction caused by it was obliterated. In addition, possible malignant pathologies were excluded through detailed histopathological evaluation. On the other hand, previous reviews have suggested that possible complications of surgical excision include bleeding, urethral retraction, urethral stricture, voiding dysfunction, and recurrence ${ }^{13}$. Conces et al. ${ }^{14}$ reported that the recurrence rate of $7 \%$ after urethral caruncle excision in their series of 41 cases. 
In conclusion, for women applying to emergency clinics with the complaint of acute urinary retention, it is extremely important to perform detailed urogynecological examinations and to consider pathologies that could lead to urethral obstruction such as urethral caruncles.

\section{References}

1. Çoban S, Biyık I. Urethral caruncle: Case report of a rare acute urinary retension cause. Can Urol Assoc J 2014; 8(3-4):e270-2. DOI: $10.5489 /$ cuaj.1683

2. Hizli F, Cetinkaya K, Bilir G, Basar H. Giant urethral caruncle presenting as genital prolapse. Urol J 2014; 11(4):1841-3. DOI: 10.22037/uj.v11i4.2198

3. Chiba M, Toki A, Sugiyama A, Suganuma R, Osawa S, Ishii R et al. Urethral caruncle in a 9-year-old girl: a case report and review of the literature. J Med Case Rep 2015; 9:71. DOI: 10.1186/ s13256-015-0518-7

4. Gamage M, Beneragama D. Urethral Caruncle Presented as Premature Menarche in a 4-Year-Old Girl. Case Rep Pediatr 2018; 2018:3486032. DOI: 10.1155/2018/3486032

5. Klarskov P, Andersen JT, Asmussen CF, Brenoe J, Jensen SK, Jensen IL et al. Acute urinary retention in women: A prospective study of 18 consecutive cases. Scand J Urol Nephrol 1987; 21:29-31. DOI: 10.3109/00365598709180286.
6. Marshall JR, Haber J, Josephson EB. An evidence-based approach to emergency department management of acute urinary retention. Emerg Med Pract 2014; 16(1):1-20.

7. Mevcha A, Drake MJ. Etiology and management of urinary retention in women. Indian J Urol 2010; 26(2):230-5. DOI: 10.4103/0970-1591.65396.

8. Nitti VW, Tu LM, Gitlin J. Diagnosing bladder outlet obstruction in women. J Urol 1999; 161(5):1535-40.

9. Ozkurkcugil C, Ozkan L, Tarcan T. The effect of asymptomatic urethral caruncle on micturition in women with urinary incontinence. Korean J Urol 2010; 51(4):257-9. DOI: 10.4111/ kju.2010.51.4.257.

10. Akdemir F. A Rare Cause of Acute Urinary Retention: Urethral Caruncle. Journal of Urological Surgery 2018; 5(3):209-211. DOI: $10.4274 /$ jus. 1576

11. Marshall FC, Uson AC, Melicow MM. Neoplasma and caruncles of the female urethra. Surg Gynecol Obstet 1960; 110:723-33.

12. Venyo A . Urethral Caruncles: A Review of the Literature . WebmedCentral Urology 2012; 3(6):WMC003454.

13. Verma V, Pradhan A. Management of urethral caruncle A systematic review of the current literature. Eur J Obstet Gynecol Reprod Biol 2020;248:5-8. DOI:10.1016/j. ejogrb.2020.03.001.

14. Conces MR, Williamson SR, Montironi R, Lopez-Beltran A, Scarpelli M, Cheng L. Urethral caruncle: clinicopathologic features of 41 cases. Hum Pathol 2012; 43(9):1400-1404. DOI:10.1016/j.humpath.2011.10.015. 